\title{
Archaeological surveys in areas with a high density of artefacts: analysis and interpretation proposals
}

\author{
Ignasi Grau Mira \\ Departament of Prehistory, Archaeology, \\ Ancient History, Greek Philology and Latin Philology \\ Faculty of Philosophy and Letters II \\ University of Alicante \\ PO BOX 99 \\ E-03080 Alicante (Spain)
}

This paper has a twin methodological and interpretative focus. It presents the use of geospatial technologies applied to archaeological surveying. We use the high-resolution spatial and temporal data obtained from the study of the ancient Protohistoric and Roman landscape in the eastern area of the Iberian Peninsula (present-day Alicante province) to illustrate the methodological proposals. The observed spatial patterns allow us to infer certain aspects relating to the ancient use of the land, transformations in settlement patterns and the intensification of landscape use.

Keywords: archaeological survey; GIS; settlement pattern; landscape intensification; ancient Iberia 


\section{THE RURAL LANDSCAPE AND SURFACE RECORD}

Studies of the ancient rural landscape face major challenges in identifying and explaining the archaeological vestiges. Most of the difficulties encountered during this type of research have been described in works devoted to that subject and it is beyond the possibilities of this paper to comment on and explain them (Alcock and Cherry, 2004; Mayoral and Sevillano, 2013). Nevertheless, along those initial lines we would like to refer to certain factors that, from our point of view, affect the question of the surface record.

The first variables we find are natural and include soil conditions and topographic, climatic and edaphic particularities, as well as the vegetation, all of which condition the way in which the surface is seen. The impacts on surveys range from the soil visibility conditions caused by vegetation to the effect on slope topography of landslips that lead to greater surface dispersion.

Another set of factors that conditions surveys is human secular establishment in rural environments and on farmland. Repeated occupation of the same niches blurs or erases earlier traces, making them difficult to identify and analyse. This particularly affects Mediterranean highland areas where terraces and banks have been built to parcel out farmland, mainly during the mediaeval and modern periods.

Finally, we refer to ancient establishment methods, the intensity of land use and the properties of the surface archaeological record formed over the centuries. These formation conditions affect such aspects as the survival of building remains, movable find density and the way in which wider or narrower dispersions were formed.

These factors sometimes lead to areas with a high density of surface archaeological record. These are places with high levels of dispersed remains consisting of thousands of fragments that often form virtual carpets of pottery remains covering hundreds of hectares. Sometimes they result from the superposition of pottery remains from different periods as a result of a dense historical stratification of rural sites. On occasions those extensive zones of finds are dated to a single period, which presents us with postdepositional processes and farming practices that have led to the formation of such complex spatial distributions of remains. These circumstances make it necessary to use archaeological surface investigation methodologies with multiple techniques with the aim of increasing the spatial and chronological resolution of the data obtained. Only by refining the procedures will we be able to progress in our understanding of the ancient rural landscape.

In the following article we present the methodological proposals for surveying, analysing and interpreting these zones with a high density of surface remains. Based on specific cases from the Protohistoric and Roman periods in our study area we illustrate the methods and proposals for the archaeological interpretation of the evidence. The study area is the River Serpis valley, a mountainous region in the north of the present-day province of Alicante.

In antiquity it was a territory presided over by fortified centres of a certain size from which a dense dispersed rural occupation was organised. These rural communities basically farms and small villages - are fundamental to our understanding of the ways in which the ancient territory was organised, both during the Iberian Iron Age $\left(6^{\text {th }}-1^{\text {st }} c\right.$. BC) and the subsequent Roman Imperial period ( $1^{\text {st }}-6^{\text {th }}$ c. AD). Although in the Iberian period there were some sixty settlements (Grau Mira, 2002), in the subsequent Roman period we attest approximately fifty settlements that covered the majority of the area's cultivable land (Grau and Garrigòs, 2007). Despite the importance of this dense rural occupation, it has not been studied to the same extent as the most important settlements, the Iberian oppida or the Roman villas, for which we have abundant references and analyses (Grau Mira, 2002; Grau and Segura, 2013). In order to obtain analytical documentation, in recent years we have developed a programme for surveying and analysing the rural landscape 
that allows us to recognise ancient types of settlement and land use in the area. It is with this data that we illustrate this article.

\section{SURVEYS ASSISTED BY GEOSPATIAL TECHNIQUES}

In the following lines we discuss the different investigation strategies we have developed in recent years for carrying out archaeological surveys (Fig. 1).

\subsection{Topographic analysis: LiDAR}

The topographical study of the land being surveyed is particularly important for understanding artefact dispersion. The topographic base of cultivated fields in the zones to be surveyed is generally far from flat and regular. In fact, it normally consists of plots of varied morphology ranging from rolling hills to steep slopes that have been terraced for cultivation.

These circumstances make it necessary to analyse the base terrain in order to understand the sectors that may have been affected by natural or anthropic postdepositional processes. With regard to the former, it is worth mentioning hillside landslips, in which the movement of sediments has led to the displacement of surface artefacts. Among the latter, we can highlight farming terraces and banks. The mechanical movement of earth to build up agricultural terraces tends to bring deep remains to the surface, whereas those in the area near the terrace wall are buried. We therefore need to be aware of the topographical factors that may have affected the configuration of the surface record.

To carry out this topographic analysis we used digital models of the terrain with resolutions of between 5 and 0.5 metres, with the higher resolution being used for the larger scales of approximately 10 to $30 \mathrm{~km}$. In the areas with the largest numbers of remains - evidence of a possible settlement - and their surrounding areas, we used high resolution data, with a DEM of $0.5 \mathrm{~m}$ cell size. The technique used was high resolution LiDAR spatial data digital modelling. Airborne Light Detection and Ranging (LiDAR) is an active system based on a laser sensor fitted to a plane or helicopter. This technology provides accuracy greater than $15 \mathrm{~cm}$ in height and a high density of spot heights.

Specifically we worked with the 2009 LiDAR Valencian Region flight, part of the Spanish National Plan for Territory Observation (PNOA). These data were obtained between August and October 2009 with an ALS50 scanner flown at an average altitude of $1300 \mathrm{~m}$. The scanning frequency was $32.3 \mathrm{~Hz}$, obtaining accuracy with a mean error of $0.03 \mathrm{~m}$. The average point density is $1 \mathrm{pt} / \mathrm{m}^{2}$.

To create the DEM we interpolated the points of the last pulse, removing the points for vegetation and other objects that do not belong to the terrain base. We used diverse interpolation methods that are explained in the corresponding section.

\subsection{Geolocalisation of the surface record}

In general we can speak of two basic types of survey: those whose objective focuses on the identification of "archaeological sites" - understood as specific locations in the archaeological record- and those that understand the surface of the terrain as a continuous space of land use, with different types of evidence that vary in their nature and structure (Mayoral and Sevillano, 2014, 39-42).

In our case we chose the second option to identify and analyse the spatial structure of the surface record. This means the element of record is the archaeological object, normally in the form of a pottery sherd. In a second step the remains dispersions are analysed to ascertain the greatest concentrations - which can be identified as 
settlements - and to offer other interpretations for zones with appreciably lower densities.

For our purposes we have developed a strategy of total surface cover. The task begins by dividing the space into sectors according to the current plot division of the terrain, which allows us to demarcate transects based on the limits visible in the field. The members of the survey team position themselves inside each of the plot units in parallel and approximately 3 to 4 metres apart. The surveyors are equipped with high performance GPS receivers from within the non-professional or leisure use range; the use of these devices allows us to mark the trajectory tracks and accurately georeference the selected remains. The spatial information for the localisation of pottery can processed differently to identify the different sherds whose shape and fabric permit a typological, chronological and functional attribution.

One problem with the geolocalisation process using the previously mentioned GPS devices is that it is not possible to correct the signal reception error. However, the introduction of the EGNOS system has reduced the margin of error to less than $3 \mathrm{~m}$, a perfectly acceptable distance for the working scale and mapping produced for find dispersion. This system of georeferencing finds was inspired by Mayoral et al (2009), whose proposals we have adapted to the conditions and objectives of our study cases. As we will see, in some cases the forms were selected and in others all the elements were found.

\subsection{Analysis of densities}

The localisation mapping of specific points was accompanied by maps of partial densities, a procedure that allows the generation of surfaces that are visually easy to understand and facilitate reflection on the observed spatial pattern. In making this estimation we also follow the proposal of Mayoral et al. $(2009,15)$ to use the kernel interpolation method, the kernel being a mathematical function that describes the intensity produced by each point in relation to a given radius (Wheatley and Gillings, 2002,186 ). In our cases we usually use a small radius of $20 \mathrm{~m}$, which allows us to identify variations in detail.

The result of this analysis of densities is an image of the survey zone in which it is easy to perceive the zones of greater density of remains and the empty spaces. However, it is also possible to see secondary spaces that need to be interpreted in relation to spatial and chronological aspects, such as the relationship with the topography or the overlapping of diverse chronological layers. If the correlation with the morphology of the terrain can be established by using the DEM and the previously described morphological analysis, the chronological evaluation is carried out through a detailed analysis of the pottery repertories. This is the process we describe below.

\subsection{Chronological analysis of the archaeological record}

The spatial precision offered by the geospatial technology available today has to correspond with the chronological resolution that allows us to sequence periods and discriminate between chronological phases that help us incorporate time into our study. The temporal precision depends on a detailed study of the pottery repertories found, given that virtually all the finds are of pottery.

In general, the maximum chronological resolution is provided by pottery of Mediterranean origin, which was mass-produced and has been well studied, thus giving very short time spans. Therefore the imported Attic or Italic black-glazed amphoras and Roman terra sigillata tableware, among others, contribute decisively to the chronological 
attribution. Notwithstanding the contribution of these types of pottery, we should point out that the majority of the pieces in our study cases are Iberian ware or from the Iberian tradition with a less detailed attribution. Fortunately, advances in regional research have made a decisive contribution to establishing the guidelines for the pottery repertories from the different phases of antiquity. We use the typology proposed by Mata and Bonet (1992), complemented by more detailed regional studies (Sala, 1995) or repertories from the area corresponding to Iberian sites from the $4^{\text {th }}, 5^{\text {th }}$ and $6^{\text {th }} \mathrm{C}$. BC (Grau and Segura, 2013), the $3^{\text {rd }}$ c. BC (Grau Mira, 1996; 2002) and the $2^{\text {nd }-1 \text { st }}$ c. BC (Ribera, 1990-91; Roselló and Cloquell, 2007-08). These repertories at least allow us to distinguish between the Iberian phases.

The pottery series that offers a precise chronology - terra sigillata tableware-can exhibit variations corresponding to intervals of 50 years. They allow us to observe the oscillations in the intensity of occupation based on the use of reference elements of high chronological accuracy.

\subsection{Integration into GIS platforms}

The integration of the documentation obtained using the described methods into a Geographic Information System is a determining factor for linking all the sources of archaeological information obtained through different procedures. It also allows an analysis of the correlation with geographical aspects in the study zone, such as the topography, the types of land, the hydrographic network, etc. Moreover it offers the possibility of combining the different working scales in a single setting, thus allowing transiting from a large spatial framework to another smaller one, one of the qualities of georeferenced data.

Following this brief general explanation of the survey and analysis methods, we will now describe in detail the application of the methodological proposals in two specific study cases. The objective of these studies was to reconstruct the rural landscape of the central Valencian area between the Iberian and Roman periods. On a general level, however, they illustrate the procedure that allows us to learn in detail about the spatial structure of complex rural sites.

\section{CASE 1. THE LANDSCAPE AS A PALIMPSEST: THREE SUCCESSIVE OCCUPATIONS IN A SINGLE SPACE}

The first of our study cases refers to the detailed investigation of a rural site known as El Carrascalet in the north of Alicante province (Fig. 2). There was known to be archaeological site from the Ibero-Roman-period there (Faus et al., 1987), but the generic chronology of approximately eight centuries was obviously too imprecise for a correct evaluation. Moreover, a central point in the location of the rural settlement had been identified, but there was a considerable dispersion of finds (Espí, 2001) that had not been taken into account.

With these precedents we decided to undertake an investigation that would allow us to ascertain the particularities of the rural site, its form, its chronology and the direction of the spatial dispersion of its remains. The results have been published in extenso elsewhere (Grau et al., 2012) and here we limit ourselves to summarising the general characteristics in order to highlight the methodological proposal.

Our working framework was the majority of the rural estate of approximately 18 hectares after which the settlement is named. The land is used for growing barley and is therefore devoid of vegetation and has excellent visibility of the ground in the winter months, when the fieldwork was carried out. 
Two different methods were used in the surface survey. The first, in keeping with the most traditional proposals, was based on the division of the study area into transects corresponding to the present-day cultivation plots in the form of terraces. Two sectors, designated A and B, were thus identified; they are separated by a gully that splits the area down the middle. Each sector was divided into 11 plots numbered from 0 to 10 with areas of between 800 and $2200 \mathrm{~m}^{2}$. The pottery sherds on each of these plots were counted to establish an initial approximation of the density of remains. In total 4153 pottery sherds were identified. They were mainly from the Iberian and Roman periods, although pieces of modern chronology were also found, as well as building materials, such as bricks and tiles, which are difficult to date. In summary, in Zone A the finds were distributed in the following proportions according to chronologies: 76\% Iberian, 11\% Roman, 4\% modern and $9 \%$ building materials; in Zone B the proportions were $57 \%$ Iberian, $2 \%$ Roman, 33\% modern and $8 \%$ building materials.

The results showed a clear concentration of ancient materials - Iberian and Roman - in the hillside zone that makes up the southern sector of the estate, to the south of the central gully. In this zone of dense remains there were up to 6 fragments per square metre of surface area. This may have been an ancient settlement with a size of approximately 1.1 hectares (Fig. 3).

However, this estimate needed greater spatial and chronological resolution. The first aspect, the number of surface remains, was conditioned by the morphology of the plots and the units to be observed were too large. In chronological terms, the attribution of the overall pottery assemblage to different periods masked the occupations of each phase, creating surfaces that corresponded to the aggregation of remains over time. In order to correct these distortions, a detailed analysis was made of the pottery remains it was possible to date more accurately.

The sherds with an identifiable morphology, i.e. rims and bottoms that allowed a typological and therefore a chronological and functional attribution, added up to a total of 611 pieces. This collection of reference pottery was subjected to a detailed analysis from both a spatial and a temporal perspective. The chronological study offered the possibility of delimiting the temporal margins of the occupation within precise limits, distinguishing the finds that were specifically Iberian - dated between the $3^{\text {rd }}$ and $1^{\text {st }} \mathrm{c}$. $\mathrm{BC}$ - and Roman -dated from the late $1^{\text {st }} \mathrm{c}$. $\mathrm{BC}$ to the $2^{\text {nd }} \mathrm{c}$. AD-; they were further divided into phases. There was also a third group of pottery finds from the modern period (18 ${ }^{\text {th }}-19^{\text {th }}$ C. AD) linked to an old farmhouse that is still there (Fig. 4).

For the spatial study we mapped the Iberian and Roman period reference pieces that had been found in the field using GPS, with the aim of observing the distribution of the evidence in each of the phases. The localisation maps of specific points (Fig. 4) were accompanied by maps of partial densities (Fig. 5) according to the previously described kernel interpolation. The result is an image of the survey zone in which it is easy to make out the zones with the highest density of remains in each period.

The results offered by the different survey techniques led us to conclude that El Carrascalet had been occupied during the Iberian and Roman periods. The high frequency of ancient pottery remains - thousands of sherds and sectors with very high densitiesleft no room for doubt. The years of continuous farming - especially the construction of terraces and deep ploughing - would have completely dismantled the habitat. Soil movements had also led to the displacement of the pottery vestiges, both horizontally along each terrace and vertically with the shifting of the earth to build the banks. The result is a dispersion of the original deposits over a wide area. Nevertheless, a detailed study of the dispersion of the finds and their relation to the topographic image of the occupation offers us the possibility of interpreting the use of the space in each of the periods analysed (Fig. 6). 
The pottery remains for the Iberian occupation were found dispersed over the entire survey area, covering approximately 15 hectares. This extensive area cannot be considered to have been the site of the settlement, as while the density is notable in some zones, in others the dispersion is very tenuous. Neither can we consider the appearance of these sherds over such a large area to have been caused exclusively by dispersion from a nuclear area due to post-depositional processes such as ploughing or landslips on slopes. Those processes would not explain such an extremely wide spread nor how the dispersion was able to surpass the physical barrier of the gully running through the middle of the site.

Firstly, the highest rates of total density, with an average of 5 sherds per $\mathrm{m}^{2}$, delineate an area of approximately $10000-9000 \mathrm{~m}^{2}$. Given the high density and variety of usage types - storage vessels, tableware, amphoras and cookware- we can consider the finds to be evidence of an ancient residential zone. This extensive settlement could have been a habitat made up of an agglomeration of various-households and could be considered to have been in the category of a village, as defined in previous works (Grau Mira, 2002: 119-120). This settlement lacks evidence of solid constructions that would allow the definition of a perimeter wall enclosing the space, although it may have had an earthen terrace to level out and adapt the terrain of the slope on which the habitat was located.

Next to the area we identify as the habitat space, farther down the hillside there is an area of average find density to which we have alluded in the sketch as an area of intensive use, where there may have been secondary facilities of a productive nature, such as sheds or vegetable or fruit growing. In this area a large amount of domestic waste was deposited; however, as it is downhill from the main site, we cannot rule out the possibility that this was carried there by the effects of gravity or surface runoff or by the earth movements involved in the construction of the modern terraces.

What to us is more interesting and more difficult to interpret is the localisation of storage pottery remains almost exclusively from the Iberian period at a distance of 300 metres from the habitat site. In our opinion, due to its low density this dispersed evidence cannot be interpreted as settlements or as the result of post-depositional displacement. If gravity were to blame, the dispersion of the remains could only have been to the east, down the hillside; it is however impossible that they would have been able to cross the deep gully that runs through the middle of El Carrascalet.

The remains are too far away for them to have been taken there purely by natural phenomena or during the earth movements for the building of the modern-period agricultural terraces. Moreover, if they had been the result of indiscriminate earth movements they would contain materials from all the periods. In fact the tenuous dispersion only affects Iberian finds, which we interpret to mean that the movement took place during that phase. We interpret this pattern of dispersal as evidence of cultivated fields being fertilised with domestic remains. The fertilisation of the land under cultivation with anthropic contributions of rubbish generated in the habitat would have led to the displacement of these sherds from pottery that had been discarded at the end of its useful life. Some researchers have plausibly suggested that they may be the remains of fertilisation with domestic waste (Wilkinson, 1982; Bintliff and Snodgrass, 1988; Nuninger, 2002, 159-174) and we believe that this is the type of farming practice that led to the pattern of tenuous pottery dispersions seen at El Carrascalet.

The evidence from the Roman period, on the other hand, describes a somewhat simpler pattern. This second period of occupation would have continued on from the previous Iberian occupation and lasted from the late $1^{\text {st }} \mathrm{c}$. BC to the late $2^{\text {nd }} \mathrm{c}$. AD. After 200 AD the site would still have been frequented, but with an appreciably lower level of activity, although with two specific peaks in the mid-4th and mid-7th $\mathrm{c}$. AD. 
During this phase of Roman occupations we only find one sector we interpret as a residential area due to the high density of remains: more than 6 fragments per $\mathrm{m}^{2}$ covering approximately $4000 \mathrm{~m}^{2}$ (Fig. 6). We lack criteria to define this settlement, as we know nothing of its structures, although there are elements that allow us to attribute a certain importance to it. For example, the remains of worked ashlars, marble plaques and abundant bricks and tiles have been found, evidence of a solid construction of a certain distinction, perhaps a villa-type settlement.

Finally, the whole zone is covered, without localised concentrations, by dispersed pottery from the modern period $-18^{\text {th }}$ - $19^{\text {th }}$ c. - , which is found together with the ancient remains. It can be linked to the agriculture associated with the farmhouse on the estate and would be the remains of more recent fertilising.

\section{CASE 2. BEYOND THE APPARENT: CONTINUITIES AND CHANGES IN THE OCCUPATIONS IN ANTIQUITY}

Our second study case has similar features, but also significant differences. On the one hand, the fact that they are in the same region and historical period means that the features of the surface evidence patterns are similar and basically characterised by the intensive distribution of materials over extensive areas with variable densities. Once again the challenge is the detailed identification of the spatial structure and chronological sequence, pinpointing the different phases and explaining how such extensive areas of evidence, sometimes of high density, came to be formed.

In this specific case we had the evidence from a Roman-period rural site known as La Torre Redona, which had building remains identified in previous investigations (Faus et al., 1987). In a test trench barely two metres long dug in 1982, archaeologists found Roman walls and materials that allowed the site to be dated to between the $1^{\text {st }}$ and $4^{\text {th }} \mathrm{c}$. AD (Grau and Garrigòs, 2007). Subsequent surveys were able to attest the existence of a concentration of materials identified as settlements, to which widespread dispersions could be added (Espí, 2001). Our task, therefore, was to make a detailed analysis of the surface remains and their variable densities and precise chronologies. In this case we had to answer two specific questions:

a) The chronological characterisation of the occupation between the Iberian and Roman phases.

b) The size of the areas where remains appeared and the possible identification of habitational structures and other non-residential evidence associated with intensive rural practices related to pottery halos.

The geolocalisation survey allowed us to situate spatially all the fragments dated to antiquity. In total, 5866 pottery sherds - mainly Iberian and to a lesser extent Romanwere localised over an approximate surface area of 60 hectares (Fig. 7). Finds of modern materials were considered too few to take into account. They were recorded in the field diaries, but not included in the GPS geolocated data.

That point cloud was used to create density maps based on the previously described kernel interpolation. As in the case of El Carrascalet the following step required the classification and interpretation of the different degrees of density; in this case we identified four ranges (Fig. 8):

A. Spaces devoid of ancient occupation. remains.

B. Very high density areas located near the previously identified Roman building 
C. Medium- to high-density halos forming an areola distributed in a radius of $500 \mathrm{~m}$ around the zone of greatest density.

D. Secondary densities inside the aforementioned areola. They are clearly visible packets of greater density.

The interpretation of the first two sectors - Zones A and B- was obvious. The empty spaces had never or hardly ever been used in antiquity, while the zone with a concentration of evidence showed all the signs of Roman settlement. The surface survey indicated an area of high density concentrated mainly in a zone of approximately 1.2 hectares in the shape of a trapezoidal field in the highest part of the rural estate, next to the hillside (Fig. 8 ). This space is next to the previously located Roman building remains and allowed the size of the settlement to be determined. Pottery analysis dated this Roman settlement to between the $1^{\text {st }}$ and $2^{\text {nd }} c$. AD (Grau et al., 2015).

We analysed the halos of average density around the concentration of remains Zone $\mathrm{C}$ - through their link to the cultivated slopes and terraces. From this we concluded that they were due to the displacement of sediments that took with it materials from the Roman settlement in the nearest zones. Those farther away would have been the dispersion of domestic waste used for fertiliser.

The challenge then was to make sense of the smaller concentrations, sectors D. These were small deposits of materials that were topographically disconnected from the main site; they could not be explained by landslips and it was shown that they were in their original place and had not been displaced. Three minor densities of approximately $300-500 \mathrm{~m}$, possibly corresponding to small settlements other than the principal occupation, were isolated (Fig. 8).

Analysis of the pottery types found in these small concentrations allowed their nature to be specified. Firstly, there was pottery for various storage functions and domestic table- and cookware corresponding to a small settlement. Secondly, we attested the absolute predominance of Iberian materials and a complete absence of the fine Roman tableware that is very frequent in Concentration $\mathrm{C}$, in the south of the study area.

With these arguments it is plausible to believe that we are looking at small hut-type sites made of perishable materials of the kind attested in other parts of the region (Espí et al., 2007). The exact chronology of these sites is difficult to establish, but they can definitely be attributed to the Iberian period, prior the main Roman site.

The spatial and chronological refinement of the surface survey procedure has allowed us to identify these small sites that predate the main site and are spatially much smaller. They are, in our opinion, the much ravaged vestiges of Iberian occupations in the form of flimsy habitats that with other methodologies may well have gone unnoticed, given the more solid evidence of the main Roman site.

In conclusion, the techniques we used allowed us to recognise a prominent Roman settlement and its predecessors in the shape of smaller settlements from the preceding Iberian period. Moreover, on a larger scale, they allow the spatial layout and different uses of the space to be sketched out (Fig. 9). Based on these data we can reconstruct an organisational layout showing the locations of the residential and working areas, those of intensive use - possibly vegetable plots-, auxiliary areas and even farmed areas.

\section{FINAL REMARKS: TOWARDS A DETAILED READING OF THE SURFACE RECORD}

Our aim in the previous pages has been to present both the general survey technique proposals and their specific application in two study cases. This research has allowed us to make progress in our understanding of how the ancient landscape in the study area was organised and its relationship with the historical dynamic of the region, as 
we have described in other studies (Grau 2014; Grau et al., 2012; Grau et al., 2015). Our aim now is to evaluate the possibilities of applying this analytical method to other archaeological contexts that share the same high densities of surface pottery finds and to propose some lines along which to reflect on this type of archaeological space.

\subsection{Beyond the settlement}

As we have stated above, the main objective of archaeological survey techniques should be the comprehension of how the societies being studied managed their rural space. In this way we can identify the different potential uses of the land, ranging from residential to preparing the ground for farming.

Obviously, the identification of habitat sites and the possibilities of ascertaining their characteristics are of prime importance. Understanding the forms of habitation at a specific time allows us to analyse the settlement patterns and through this to reach conclusions on the model of economic, social and political organisation. However, the possibilities do not end there, as the way the land was managed is just as important as the forms of habitation. In this way, the existence of tenuous pottery dispersions interpreted as settlements prompts us to be aware that domestic waste from nearby plots may have been used as fertiliser. This opens up the possibility of identifying the sizes of the agricultural estates or the farming intensification processes that need to be interpreted within their economic and social coordinates (Grau Mira, 2014).

\subsection{Spatial and chronological refinement}

Likewise, the precision attained in the data collection and its interpretation allows us to profile in increasing detail the spatial structure of the rural sites and their sequences of occupation with increasingly accurate chronological margins. Without doubt the current generalisation of geographical information data, such as aerial photography, thematic maps, digital elevation models, etc., as well as some of the more sophisticated geospatial techniques, such as geophysics, LiDAR, etc., augur a promising future.

Although the spatial resolution is important, we must not neglect the chronological evaluation of the vestiges, especially the pottery, the features of which allow us to attribute it to well-dated series. In some territories it can reveal transformation processes that had been masked by the high density of remains. For example, the dispersions of pottery with an apparently identical ancient dating may actually correspond to two successive phases, in our case the Iberian and Roman periods. This procedure allows subtle changes to be detected in the location and size of the settlements or in the dispersion of remains in nearby fields, which under other circumstances would go unnoticed and would not be included in the interpretations.

\subsection{Intensified use of the landscape}

The analysed evidence allows us to present a case of intensified use of the landscape within the general framework of the long-term transformation processes. In this respect, we can clearly emphasise the organisational differences between the Iberian and Roman periods in the management and exploitation of the countryside, although we can also point out the continuity of the transformation dynamic in the Mediterranean area.

In the Iberian period $-4^{\text {th }}$ to $1^{\text {st }} \mathrm{c}$. $\mathrm{BC}$ - we can link the intensification of agriculture to a process of political centralisation and the emergence of local powers in the Iberian territories. The existence of a ruling social group residing in the fortified high-ground settlements implied tributary obligations for the peasant groups living in the surrounding countryside. This requirement impelled the development of intensive farming to provide the resources needed to meet this social demand. 
Later, from the $1^{\text {st }}$ to the $4^{\text {th }} \mathrm{c}$. $\mathrm{AD}$, Roman domination led to the establishment of new forms of land management and ownership and the emergence of new settlements and exploitation methods. Despite the major reorganisations of the sociopolitical system, the small peasant units continued with similar intensive uses based on traditional practices and knowledge of the territory.

In this respect, this case study, with an analysis based on refined archaeological surveys, is another example of intensive agricultural producers (Netting 1993) operating in different social contexts. Therefore it can contribute to the general discussion on the processes of intensified use of the landscape and the increasing human influence on the formation of anthropogenic landscapes in other regions and contexts.

\section{Acknowledgements}

I thank M. Navazo, J. Jordá and A. Maximiano for the kind invitation to participate in this edited volume. This work was supported by the MINECO under Grant HAR2012-37003C03-02.

\section{BIBLIOGRAPHY}

ALCOCK, S., CHERRY. J.F. 2004. Side by Side Survey. Comparative Regional Analysis in the Mediterranean Region. Oxford: Oxbow Books.

BINTLIFF, J., SNODGRASS, A. 1988. Off-Site Pottery Distributions: A Regional and Interregional Perspective", Current Anthropology 29 (3): 506-513.

ESPÍ PÉREZ, I. 2001: Noves dades sobre el poblament ibèric i romà a les comarques de l'Alcoià i del Comtat. Les Valls de les Puntes, Polop, Serpis mitjà i Alcalà, Recerques del Museu d'Alcoi 10, 83-110.

ESPÍ PÉREZ, I., GRAU MIRA, I., LÓPEZ SEGUÍ, E., TORREGROSA JIMÉNEZ, P. 2009. La aldea ibérica de l'Alt del Punxó: producción agrícola y asentamiento campesino en el área central de la Contestania, Lucentum 28, 23-50.

FAUS BARBERÁ, J., ARAGONÉS , V., FAUS CARDONA, J., PLA PERALES, R. 1987. Un catálogo de yacimientos arqueológicos en la montaña alicantina, Alcoi.

GRAU MIRA, I. 1996. Estudio de las excavaciones antiguas de 1953 y 1956 en el poblado Ibérico de La Serreta, Recerques del Museu d'Alcoi 5, 83-119.

GRAU MIRA, I. 2002. La organización del territorio en el área central de la Contestania Ibérica, Universidad de Alicante.

GRAU MIRA, I. 2014. The rural landscape of the Valley of Alcoi in the eastern Iberian Iron Age: agricultural intensification and sociopolitical dynamics. Journal of Field Archaeology, 39, $124-133$.

GRAU MIRA, I., GARRIGÓS i ALBERT, I. 2007. Aproximació al poblament romà de les Valls d'Alcoi, Recerques del Museu d'Alcoi 16, 113-150.

GRAU MIRA, I., SEGURA MARTÍ, J.M. 2013. El oppidum ibérico de El Puig d'Alcoi. Asentamiento y paisaje en las montañas de la Contestania, Ajuntament d'Alcoi- Museu Arqueològic Camil Visedo.

GRAU, I., CARRERAS, C., MOLINA, J., DE SOTO, P., SEGURA, J.M. 2012. Propuestas metodológicas para el estudio del paisaje rural antiguo en el área central de la Contestania, Zephyrus LXX, 131-149. 
GRAU, I., CARRERAS, C., CORTELL, E., CORTÉS, A., MIRÓ, J., MOLINA, J., SEGURA, J.M. 2015. L'assentament de Torre Redona (Alcoi) i la formació del paisatge romà a l'Alcoià-El Comtat. Recerques del Museu d'Alcoi 24, 67-86.

MATA PARREÑO, C., BONET ROSADO, H. 1992. La cerámica ibérica: Ensayo de tipología. Estudios de Arqueología Ibérica y Romana: Homenaje a Enrique Pla Ballester, Servicio de Investigación Prehistórica, Diputación Provincial de Valencia (Trabajos Varios del SIP, 89), 117-174.

MAYORAL, V., SEVILLANO L. 2013. Prospección, paisaje y "el gran cuadro" de la historia agraria: una revisión crítica y algunas propuestas. Comechingonia. Revista de arqueología 17 (2), 31-56.

MAYORAL, V., CERRILLO, E., CELESTINO, S. 2009. Métodos de prospección arqueológica intensiva en el marco de un proyecto regional: el caso de la comarca de La Serena (Badajoz), Trabajos de Prehistoria 66 (1), 7-25.

NETTING, R.M. 1993. Smallholders, Householders: Farm Families and the Ecology of Intensive, Sustainable Agriculture. Stanford: Stanford University Press

NUNINGER, L. 2002. Peuplement et Territoires protohistoriques du VIIe au Ier siècle avant J. C. en Languedoc (Gard-Hérault), Ed. Univ. Franche Comté, Besançon.

RIBERA, A. 1990-91. El jaciment ibéric del Teular de Mollà (Ontinyent). L'excavació arqueològica de salvament de 1989, Alba 5-6, 29-54.

ROSElLÓ, P., CLOQUELL, S. 2008-09. El jaciment ibèric de l'Hort de la Torre (Vilallonga, València), Recerques del Museu d'Alcoi 17-18, 173-182.

SALA SELLÉS, F. 1995. La cultura ibérica de las comarcas meridionales de la Contestania entre los siglos VI y III a.C., Institut de Cultura Juan Gil-Albert, Alicante.

WHEATLEY, D., GILLINGS, M. 2002. Spatial technology and archaeology. The archaeological applications of GIS, Ed. Taylor \& Francis, Londres.

WILKINSON, T. 1982. The definition of ancient manured zones by means of extensive sherd-sampling techniques, Journal of Field Archaeology 9, 323-333. 


\section{Figures}

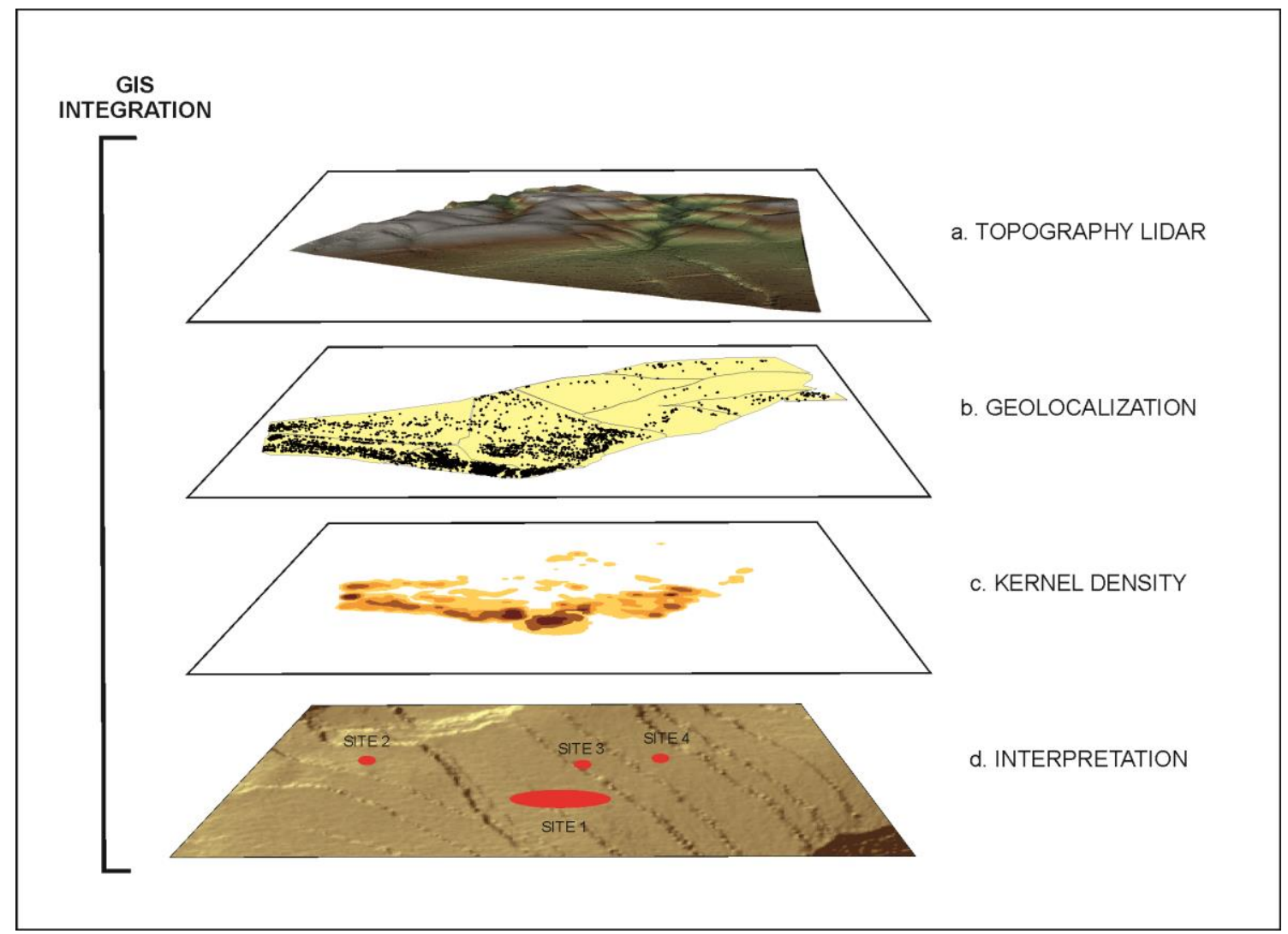

Figure 1. Scheme of the proposed survey analysis and interpretation.

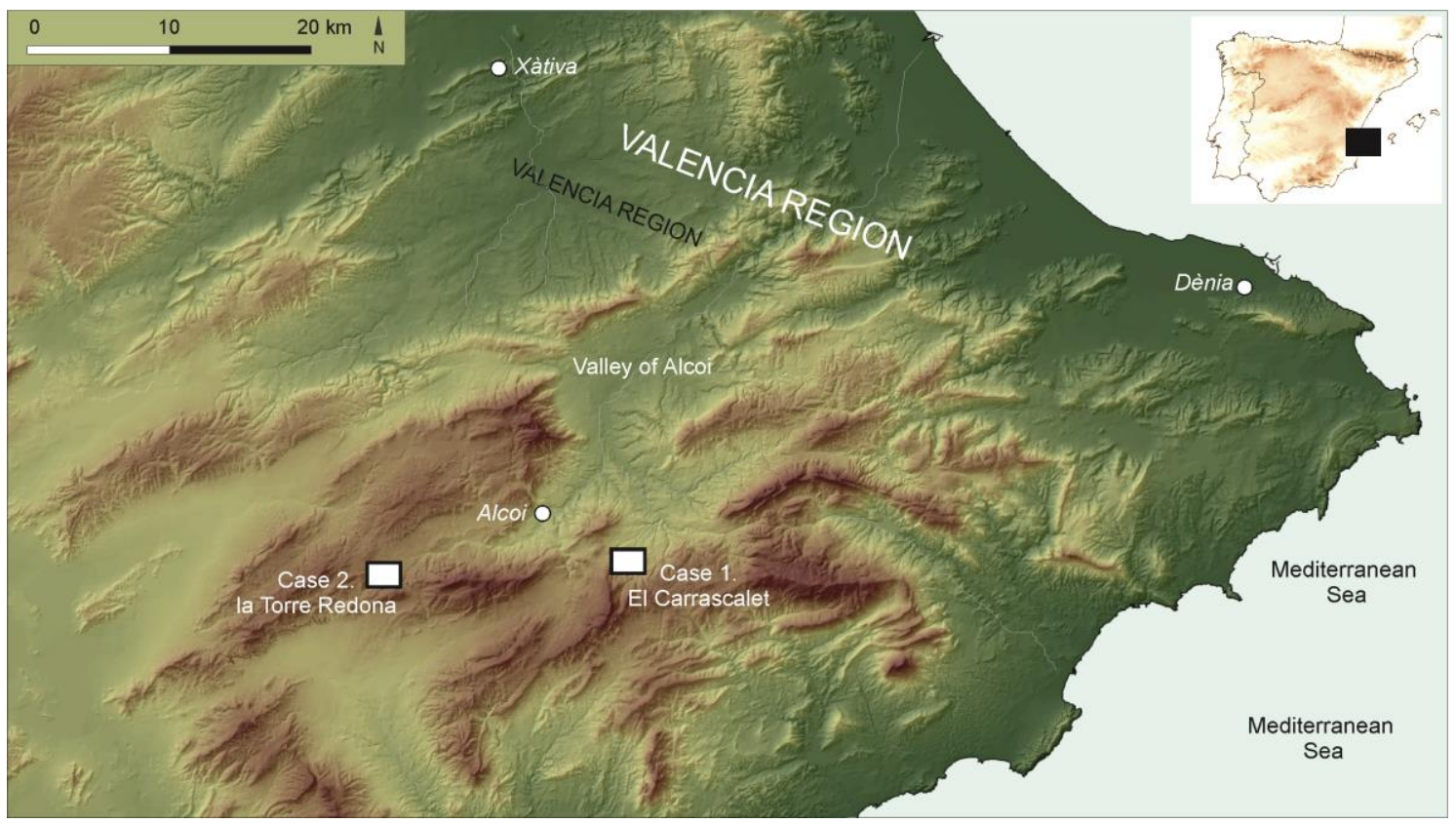

Figure 2. Map of the area with the localization of the two cases of study and the main current towns 


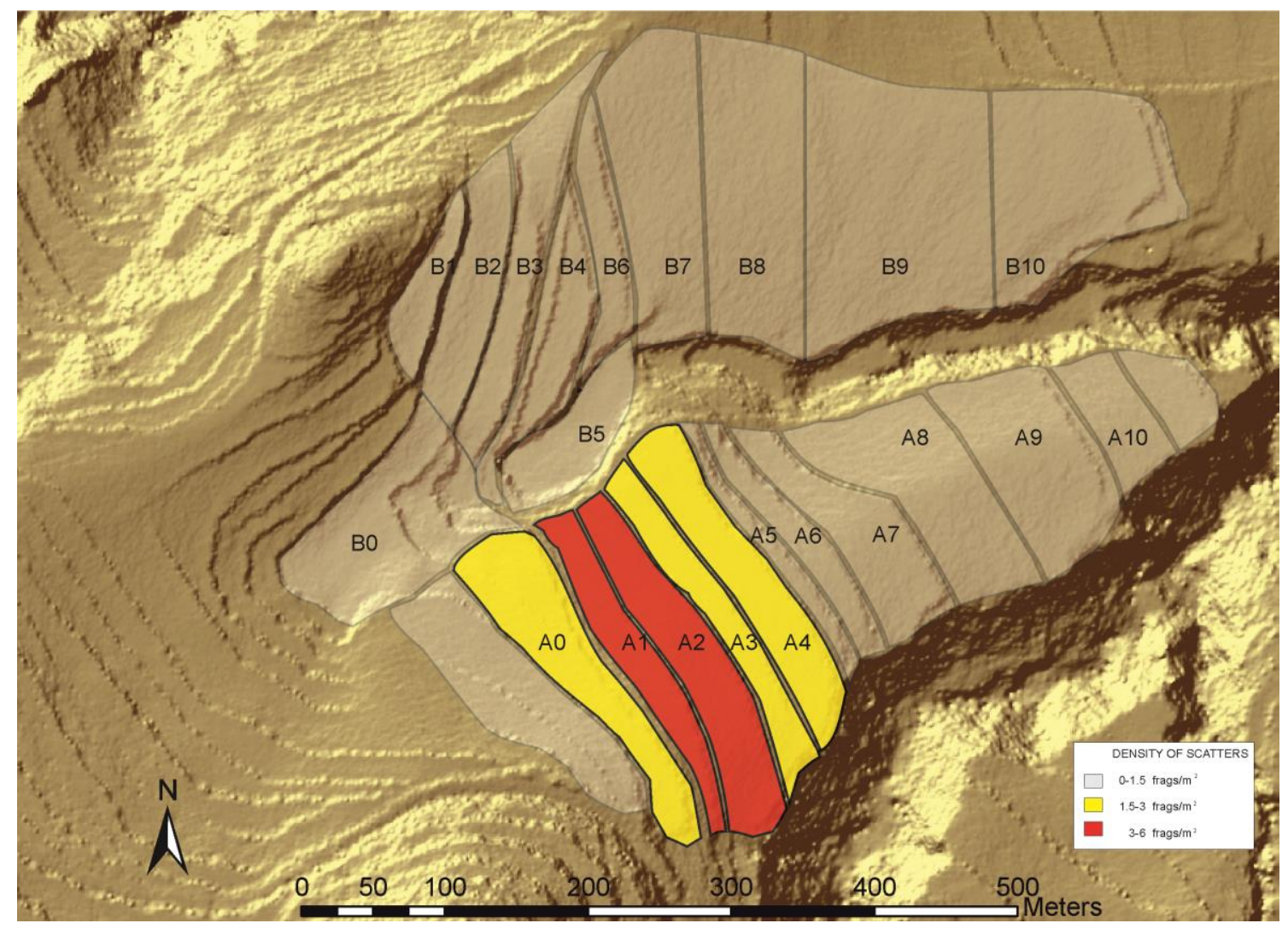

Figure 3. Digital elevation model of El Carrascalet (Case 1) with the survey transects. The colors show the different densities of pottery in the surface.

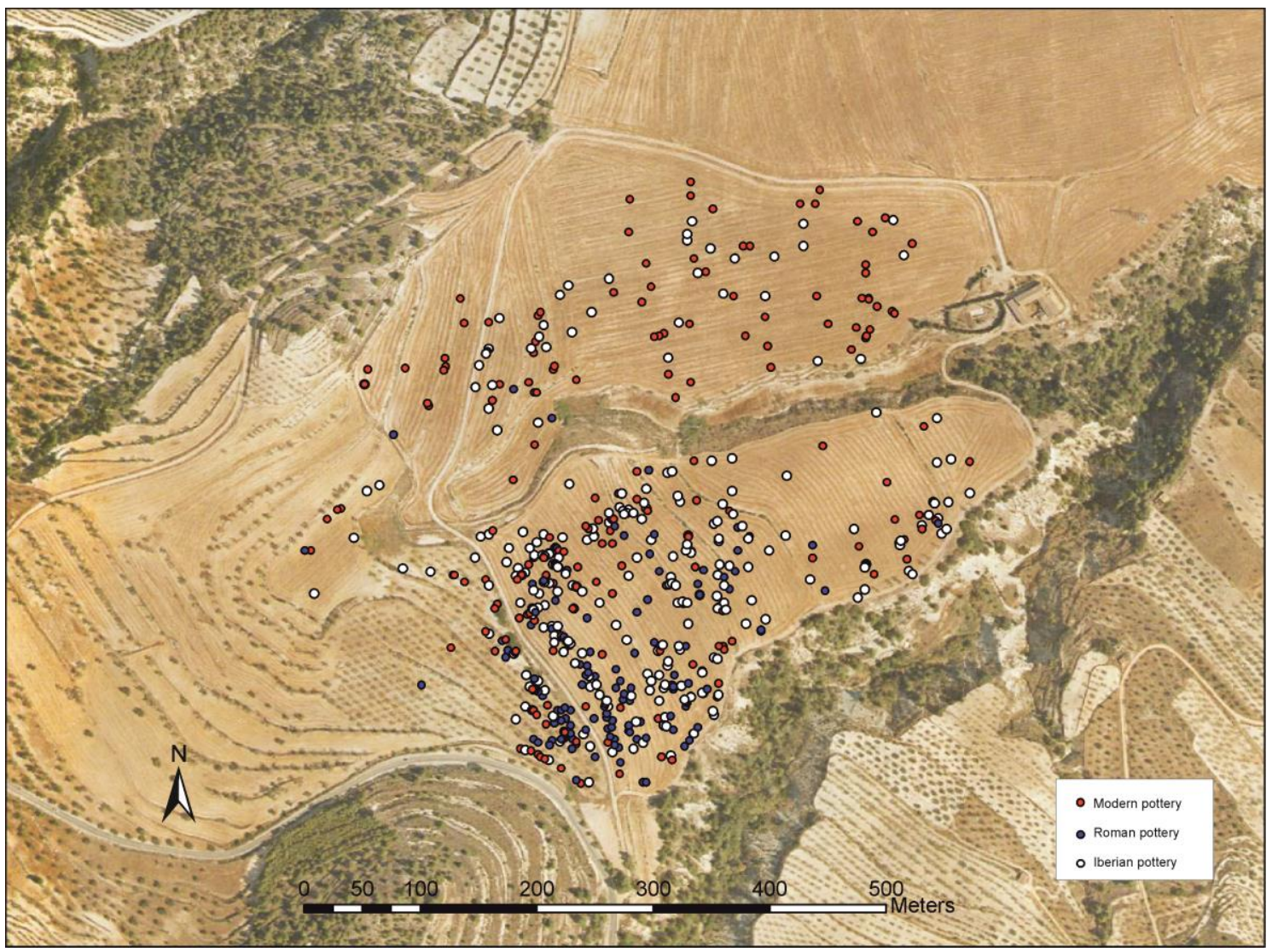

Figure 4. Aerial photography of El Carrascalet with the geolocalization of diagnostic pottery by periods ( 611 points). 

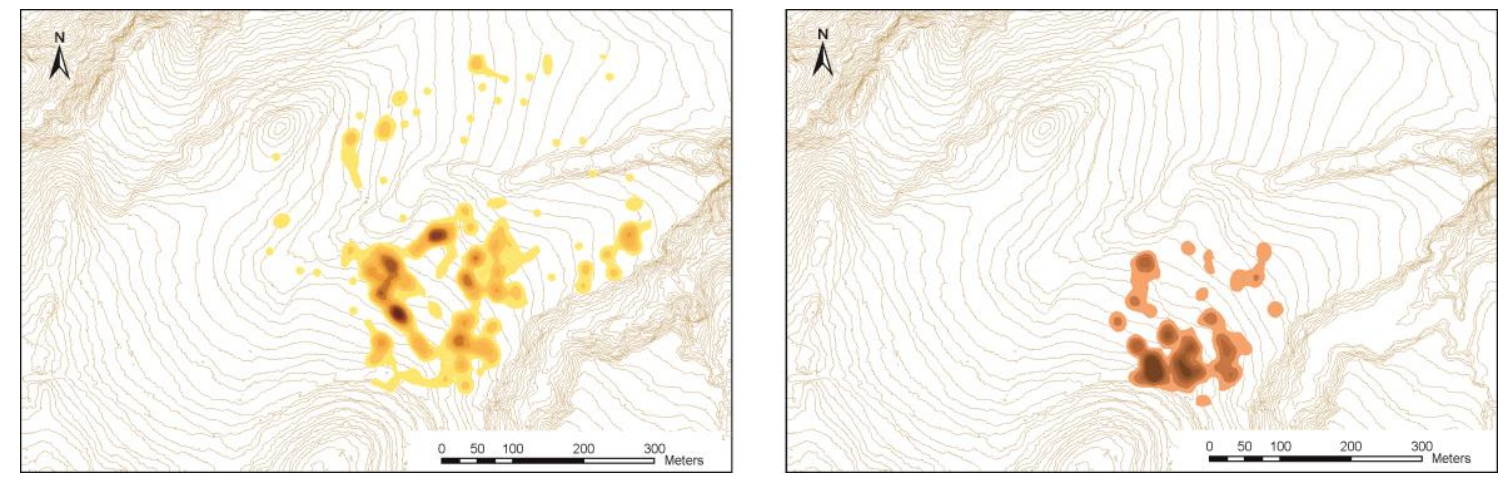

Figure 5. Contour map of El Carrascalet with the kernel interpolations of materials from Iberian period (left) and Roman period (right)
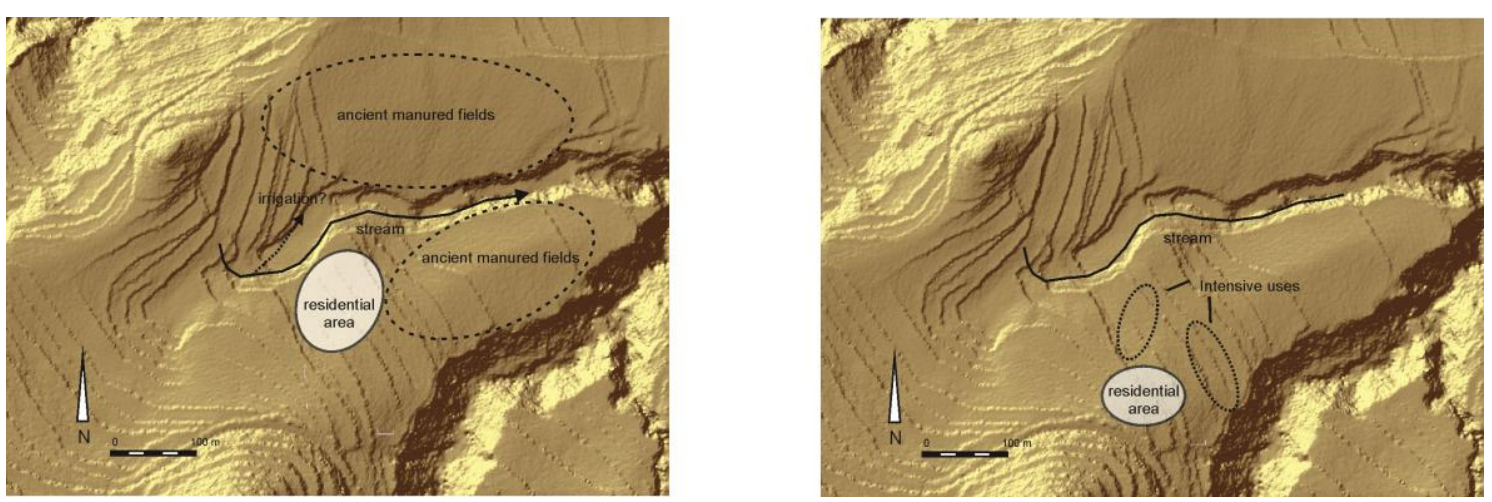

Figure 6. Digital elevation model of El Carrascalet with the interpretaction of the uses of space from Iberian period (left) and Roman period (right) 


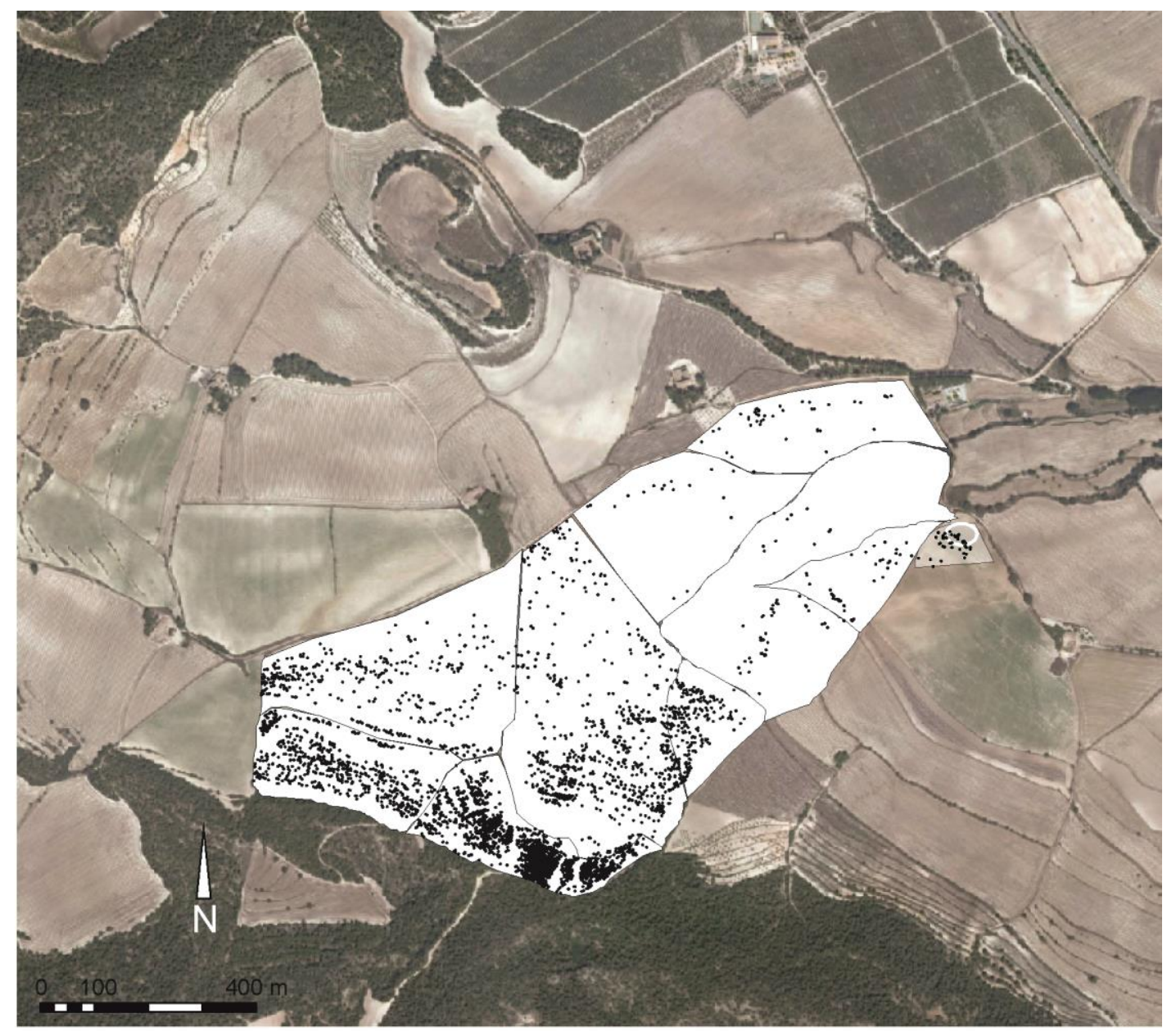

Figure 7. Aerial photography of La Torre Redona (Case 2) with the geolocalization of ancient pottery (5866 points).

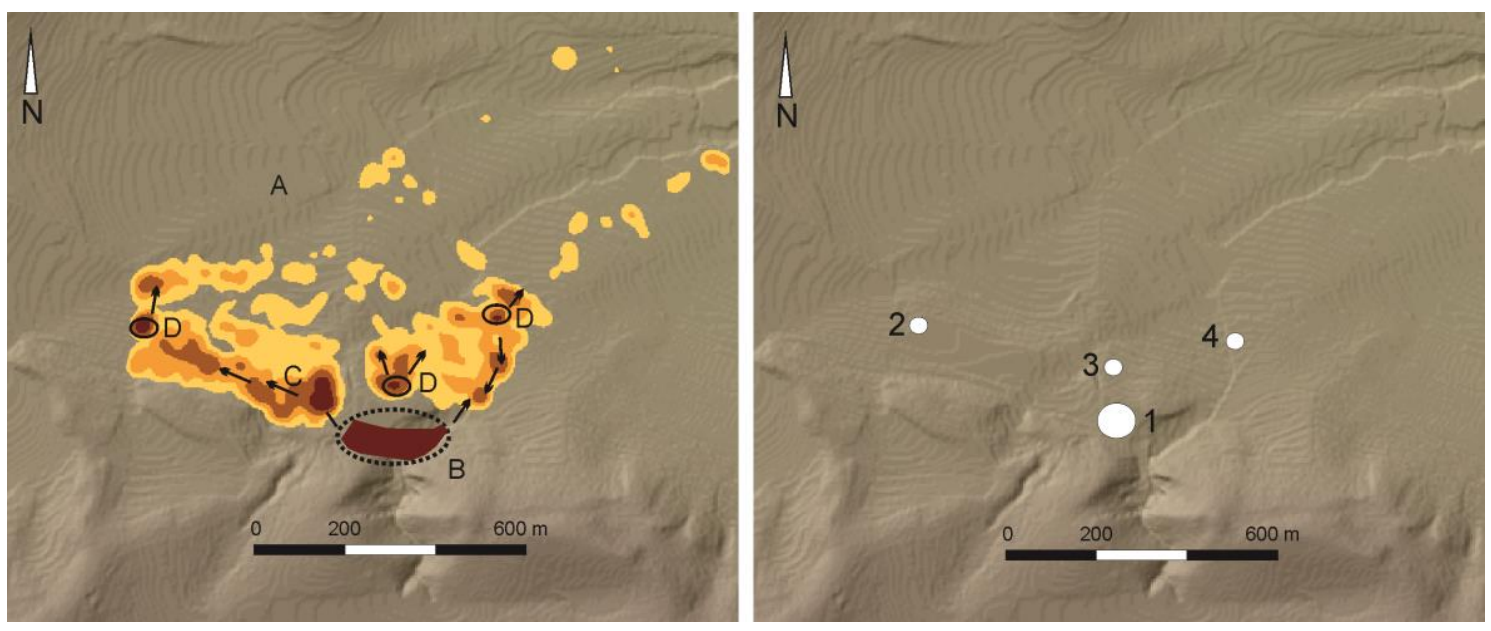

Figure 8. Left, digital elevation model of La Torre Redona with the kernel interpolations of materials and the interpretative classification. A: Empty Spaces. B: Roman settlement; C: Intensive uses; d: secondary sites. Right, identification of the Roman settlement (1), and the Iberian sites $(2,3$ and 4$)$ 


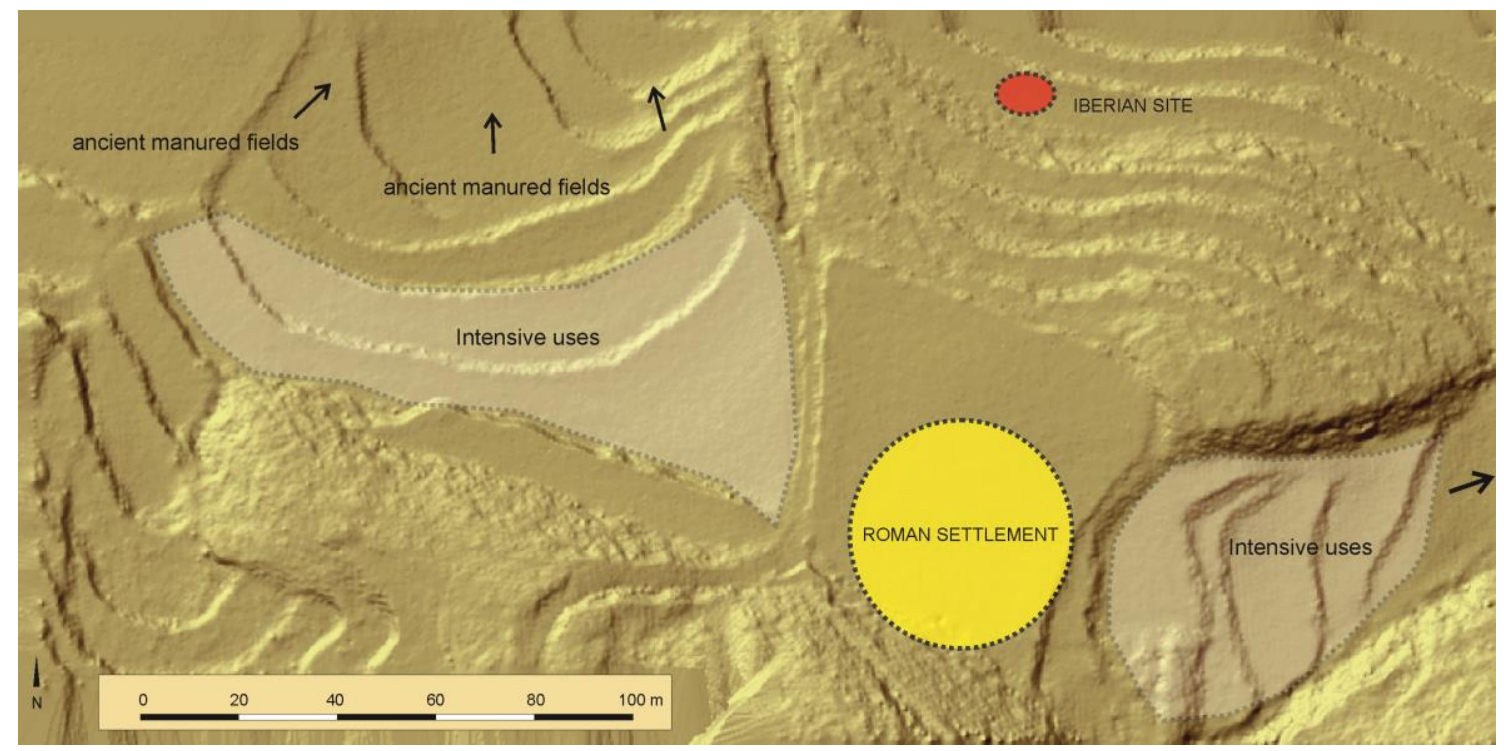

Figure 9. Digital elevation model of La Torre Redona with the interpretation of the uses of spaces. 